СУЧАСНИЙ СТАН ПІДГОТОВКИ МАЙБУТНІХ УЧИТЕЛІВ МАТЕМАТИКИ ЗАСОБАМИ ІНФОРМАЦІЙНО-КОМУНІКАТИВНИХ ТЕХНОЛОГІЙ У СИСТЕМІ НЕПЕРЕРВНОÏ ОСВІТИ

\title{
CURRENT STATE OF PREPARATION OF FUTURE TEACHERS OF MATHEMATICS BY INFORMATION AND COMMUNICATION TECHNOLOGIES IN CONTINUOUS EDUCATION SYSTEM
}

Стаття присвячена проблемі неперервної професійної підготовки майбутніх вчителів математики з використанням інсрормаційно-комунікативних технологій, адже модернізація професійної підготовки майбутніх учителів $є$ однією з головних ланок реформи вищої освіти в Україні. У статmі проведено аналіз шкільної математично освіти та ситуацій вступу абітурієнтів до вищих навчальних закладів упродовж декількох останніх років. Акцентовано, що математичні науки відіграють особливу роль у житті суспільства, оскільки саме вони слугують розвитку науково-технічного і технологічного прогресу, визначають престиж країни на світовій арені. У цьому контексті важливою $є$ якість професійної підготовки майбутніх учителів математики до подальшої професійної діяльності, яка спирається на використання різноманітних інноваційних педагогічних форм, методів i засобів на основі інорормаційно-комунікативних технологій. У статті розглянуто сучасний стан підготовки майбутніх учи телів математики та вказано напрями вдосконалення професійної підготовки студентів педагогічних вишів, зокрема майбутніх вчителів математики у системі неперервної освіти, адже підготовка майбутніх вчителів математики за новими освітніми стандартами вимагає активізації самостійної роботи студентів, яка дозволяла б поряд із предметними знаннями опановувати види діяльності, характерні для майбутньої профресійної діяльності. Виокремлено складові частини системи профессійної підготовки майбутніх учителів математики (змістову, технологічну, особистісну). Визначено головні ознаки новоі моделі підготовки студентів: фокусування уваги на необхідності отримання освіти протягом усього життя; перетворення бакалаврату в ядро освітньої системи; надання студентам широкого аспекту систематично оновлюваних магістерських програм, програм профресійної та загальнокультурної підготовки та перепідготовки; в системі безперервної освіти ключовим фрактором стає самостійний доступ студентів до навчальних ресурсів та інновачійних технологій самоосвіти; менеджмент якості освіти на основі бально-рейтинговоі системи для оцінки рівня оволодіння студентами навчальними дисциплінами.
Ключові слова: вчитель математики, електронні освітні ресурси, неперервна професійна підготовка, практика, інфрормачійн технології.

The article is devoted to the problem of continuous professional training of future mathematics teachers using information and communication technologies, since modernization of future teachers' professional training is one of the main links of the higher education reform in Ukraine. The analysis of school mathematical education and the situations of students' admission to higher education during the last few years is conducted. The article emphasizes that the mathematical sciences play a special role in the life of society, because they serve the development of scientific, technological and technological progress, determine the prestige of the country on the world stage. In this context, the quality of professional training of future mathematics teachers for further professional work, which relies on the use of various innovative pedagogical forms, meth ods and tools based on information and communication technologies, is important. The article deals with the current state of preparation of future mathematics teachers and indicates directions of improvement of professional training of students of pedagogical universities, in particular of future mathematics teachers in the system of continuous education, since the preparation of future mathematics teachers according to new educational standards requires a lot of work. master those activities that are characteristic of future professional activity. The components of the system of professional training of future mathematics teachers (content, technological, personal) are separated. The main features of the new model of student preparation are identified: focusing on the need for lifelong learning; transformation of the bachelor's degree into the core of the educational system; providing students with a broad aspect of systematically updated masters programs, vocational and general education and retraining programs; in the system of continuous education independent access of students to educational resources and innovative technologies of self-education becomes a key factor; quality management of education on the basis of a point-rating system for assessment of students' mastery of educational subjects. Key words: mathematics teacher, electronic educational resources, continuing vocational training, practice, information technology.
Постановка проблеми у загальному вигляді. Теперішній стан підготовки майбутнього вчителя математики характеризується стрімким розвитком математичної науки, численними ресормами освіти, але водночас спостерігається скорочення годин на аудиторні заняття та збільшення частки самостійної роботи студентів. Проблеми, які вини- кають під час просресійної підготовки майбутніх учителів математики у педагогічному ВНЗ, можуть бути вирішені за рахунок використання ЕОР. Ocoбливо актуальним у процесі підготовки майбутніх вчителів математики $€$ вивчення фундаментальних дисциплін, яке повинне відбуватися із застосуванням інформаційних технологій. 
Аналіз основних досліджень і публікацій. Проблеми професійної підготовки майбутніх учителів математики широко досліджують сучасні українські та зарубіжні науковці, серед яких М. Бурда, Н. Віленкін, Б. Ерднієв, М. Жалдак, М. Ігнатенко, А. Колмогорова, Т. Крилова, І. Новик, М. Левшин, Г. Михалін, А. Мордкович, В. Моторіна, О. Скафа, 3. Слєпкань, О. Співаковський, Н. Тарасенкова, Ю. Триус, М. Шкіль, М. Якубовська та ін. В останні роки як в Україні, так і за кордоном інтенсивно досліджують питання запровадження навчальний процес інорормаційних технологій: В. Биков, Л. Брескіна, М. Головань, Р. Гуревич, В. Дровозюк, І. Забара, М. Жалдак, О. Жильцов, Ю. Жук, М. Кадемія, Л. Карташова, Л. Коношевський, В. Лапинський, Т. Олійник, А. Пеньков, Ю. Рамський, Є. Смирнов, Г. Шугайло, С. Яшанов, Ч. Крук, К. Ісрофрф, М. Ліск, Хр. Ллойд, А. Лавлес, В. Редінг, І. Скенлон та ін. Зокрема, низка дисертаційних досліджень присвячена висвітленню різних аспектів проблеми професійної підготовки майбутніх вчителів математики: підготовці майбутніх учителів математики до активізації пізнавальної активності учнів у процесі навчання математики (М. Ігнатенко, М. Головань, Н. Житєньова); реалізації компетентнісного підходу в системі професійної підготовки майбутнього вчителя математики (В. Ачкан, І. Зіненко, С. Раков); підготовці майбутніх учителів математики до роботи з обдарованими учнями (Л. Радзіховська, Л. Семенець); формуванню інформаційної культури майбутніх учителів математики (Ю. Рамський); формуванню основ професійної культури вчителя математики у процесі навчання математичного аналізу (Г. Михалін); підготовці майбутніх учителів математики до застосування широких можливостей інформаційних технологій (М. Жалдак, О. Співаковський, Ю. Тріус, С. Семеріков) та ін. Погоджуючись із думкою науковців, вважаємо що підготовка майбутніх вчителів до активної діяльності в інфрормаційному суспільстві - одне 3 головних завдань сучасного етапу модернізації професійної підготовки майбутніх фрахівців у вищій школі.

Виділення невирішених раніше частин загальної проблеми. Математика якнайкраще сприяє формуванню таких здібностей в учнів, як системність мислення і дій, здатність до аналізу, абстрагування, систематизації. Математична освіта відіграє особливу роль у підготовці майбутніх фрахівців у галузі математики, інформатики, комп'ютерних та інфрормаційних технологій, техніки, виробництва, економіки, управління як у плані фрормування певного рівня математичної культури, інтелектуального розвитку, так і в плані формування наукового світогляду. Проте останнім часом спостерігається стійка тенденція зниження рівня шкільної підготовки 3 математики, що свідчить про непродуктивність мотиваційних механіз- мів, які використовують у навчанні цього предмету $[7$, c. 53].

Таким чином, важливою проблемою $є$ профресійна підготовка майбутнього вчителя математики до подальшої професійної діяльності. Попри велику кількість публікацій із цього питання, сьогодні проблеми неперервної професійної підготовки майбутніх учителів математики 3 використанням інформаційно-комунікативних технологій (далі - IKT) залишаються недостатньо вивченими і вимагають деякої корекції.

Мета статті - розглянути умови підготовки майбутніх учителів математики та вказати напрями вдосконалення профресійної підготовки студентів педагогічних вишів, зокрема майбутніх вчителів математики, у системі неперервної освіти.

Виклад основного матеріалу. Вимоги сучасного суспільства змістили акценти у професійній підготовці майбутніх учителів математики. У зв'язку зі змінами, які відбулися у суспільному житті, вкрай актуальними є питання суттєвої зміни системи підготовки педагогічних кадрів і насамперед учителів математики з огляду на концепт нової української школи

За словами В.Г. Кременя: «Майбутній учитель, учитель XXI ст., - це не просто носій певної кількості знань, він не просто володіє методикою навчання і виховної роботи, він - партнер, співучасник, провайдер у цьому величезному інфрормаційному, глобальному просторі» [2, с. 9].

Саме тому специфіка діяльності вчителя математики в умовах сучасності вимагає від нього творчого і критичного мислення, спостережливості, уміння планувати, здійснювати й аналізувати педагогічний процес, розв'язувати низку педагогічних задач, спрямованих на досягнення загальної мети - формування особистості учня, його світогляду, переконань, свідомості, поведінки.

На думку О. Біляковської, якість професійної підготовки майбутнього вчителя розглядається як відповідність рівня його професійної підготовки, з одного боку, нормативним вимогам державного стандарту та запитам і по-требам освітніх установ, 3 іншого - вимогам, які висуваються до вчителя суспільством як до професіонала, конкурентоспроможного на ринку освітніх послуг, котрий зможе професійно вирішувати завдання, пов'язані не лише із виконанням соціально значущих профресійних фрункцій, але і з розширенням спектра власної педагогічної діяльності [1, с. 126].

Якість підготовки висококваліфікованих кадрів, в т. ч. і вчителів математики, багато в чому залежить від системи відбору абітурієнтів до ВНЗ. Загальновідомо, що чинна нині в педагогічних вишах система відбору абітурієнтів страждає багатьма недоліками, насамперед зосередженням на вступних іспитах уваги лише на перевірці в абітурієнтів обсягуіхарактерупредметнихзнань,уміньінавичок. 
Практика показує, що рівень математичної підготовки майбутніх студентів не високий, і хоча 2019 р. 102 випускники отримали найвищий бал із математики, відсоток учнів, котрі не подолали поріг «склав - не склав», також зростає. Хочеться відзначити, що з кожним роком зростає кількість учнів, які вибирають на ЗНО математику, але у процентному відношенні успішність учнів із математики спадає, крім того, в педагогічні виші вступають абітурієнти не з високими балами з математики.

Аналіз результатів виконання завдань ЗНО 3 математики за 2019 р показав, що найскладнішим із розділу «Числа і вирази» виявилося завдання 3 оцінки значення логарифрмічного виразу, яке розв'язала лише третина учасників. Зі спрощенням тригонометричного виразу впоралася лише половина тестованих. Окрім того, лише близько 50\% учасників виразили одну змінну через іншу, пов'язану з першою лінійною залежністю. Ця навичка є базовою, тому що її використовують для визначення невідомих змінних упродовж усього навчання в середній, старшій і вищій школах, і не тільки в математиці. Серед учасників зовнішнього незалежного оцінювання 3 математики близько 40\% не змогли розв'язати квадратне рівняння. Водночас більше половини тестованих правильно визначили число, що $€$ розв'язком нерівності 3 модулем, майже всі тестовані (95\%) змогли визначити вид многогранника за його розгорткою, що свідчить про розуміння означення розгортки та правильне уявлення про многогранник як об'ємну геометричну фрігуру. Більше половини учасників указали основні властивості паралелограма; майже 80\% продемонстрували вміння зіставляти наведені на діаграмі дані з умовою завдання. Найбільші труднощі виникли в учасників тестування під час розв'язування завдань із розгорнутою відповіддю, 43\% тестованих навіть не спробували розв'язувати їх [5, с. 213].

Аналіз ситуації вступу абітурієнтів до вищих навчальних закладів упродовж декількох останніх років показує, що також спостерігається збільшення частки тих, хто, закінчивши школу, вибирає декілька спеціальностей. Аналіз вишівської практики показує, що сьогодні вища освіта для багатьох студентів $€$ насамперед інструментом реалізації соціальних, а не спеціально-профресійних запитів; іншими словами, студентом рухає соціальне прагнення зайняти місце в житті, а вже потім - стати професіоналом у певній сорері діяльності [3, с. 105].

Тому відбір абітурієнтів в педагогічні навчальні заклади повинен бути зорієнтований на виявлення морально вихованих людей, що мають задатки до педагогічної діяльності, і це можливо лише на основі надійного зв'язку вишу зі школами.

А.О. Теплицька вважає, що головним завданням професійної підготовки майбутніх вчителів математики $€$ оволодіння ґрунтовними теоретичними знаннями та практичними навичками 3 фахових дисциплін, а також дисциплін психологопедагогічного циклу, інноваційними практичними вміннями і навичками для роботи у загальноосвітніх навчальних закладах, фрормування особистісних якостей, потрібних для продуктивної педагогічної діяльності. Згідно 3 вищезазначеним доцільним є виокремлення у системі професійної підготовки майбутніх учителів математики трьох складових частин:

а) змістової (оволодіння спеціальними математичними знаннями);

б) технологічної (оволодіння інноваційними методами і прийомами навчання професійнофрахових дисциплін);

в) особистісної (наявність особистісних якостей, необхідними для майбутнього вчителя) [8].

На думку О. Білявської, модернізація умов і змісту освітнього простору визначає ряд чинників, які впливають на якість професійної підготовки майбутніх вчителів, таких як: якість освітніх програм і стандартів, якість підготовки абітурієнтів, інорорматичне, методичне та матеріальне забезпечення навчального процесу, кваліфрікація професорсько-викладацького складу, якість освітнього середовища, рівень наукових досліджень, що проводяться у ВН3, якість результату (якість знань, рівень засвоєння, рівень сорормованої профресійно важливих якостей особистості майбутнього вчителя та сукупність умінь і навичок, потреб до професійного й особистісного саморозвитку, готовність виконувати професійні фрункції, конкурентоспроможність) [1].

У ході аналізу шляхів модернізації професійної підготовки майбутніх учителів Є.І. Пассов виокремлює уміння, на розвиток яких слід спрямувати процес професійної підготовки:

Показники ЗНО з математики загалом по Україні

Таблиця 1

\begin{tabular}{|l|c|c|c|}
\hline \multicolumn{1}{|c|}{ Роки } & $\mathbf{2 0 1 7}$ & $\mathbf{2 0 1 8}$ & $\mathbf{2 0 1 9}$ \\
\hline Загальна кількість зареєстрованих на 3НО & 240889 & 335843 & 354051 \\
\hline Кількість зареєстрованих із математики & $113133(47 \%)$ & $112023(33,37 \%)$ & $174640(49,32 \%)$ \\
\hline \% учнів, що успішно склали 3НО & $85,91 \%$ & $84,98 \%$ & $82,3 \%$ \\
\hline \%учнів, що мали 190-200 балів & $8,98 \%$ & $9,08 \%$ & $9,11 \%$ \\
\hline \% учнів, що не подолали поріг & 14,09 & 15,02 & $17,7 \%$ \\
\hline Середній бал за шкалою 100-200 балів & 142,88 & 143,58 & 144,38 \\
\hline
\end{tabular}


1) проектувальні (вміння спроектувати, спланувати будь-який вид роботи);

2) адаптаційні (вміння застосовувати свій план у конкретних навчальних умовах);

3) організаційні (вміння організовувати будьякий вид роботи);

4) мотиваційні (вміння мотивувати учнів до навчальної діяльності);

5) комунікативні (вміння спілкуватися на навчальному заняття і поза ним);

6) уміння контролю і самоконтролю;

7) пізнавальні (вміння вести дослідницьку діяльність);

8) допоміжні (вміння співати, малювати, грати на музичному інструменті тощо) [6, с. 14].

Сьогодні система здобуття вищої професійної освіти в Україні, в т. ч. і педагогічної, змінилася новою багаторівневою системою, яка істотно відрізняється від попередньої як за змістом, так і за структурою організації. За новою дворівневою системою навчання на здобуття загальної вищої освіти відводиться чотири роки (програма бакалаврату), а на оволодіння спеціалізованими знаннями і професійними навичками - півтора-два роки (програма магістратури).

Програма бакалаврату в європейських країнах співвідноситься 3 освітніми програмами наших коледжів. У європейських країнах основна увага у підготовці бакалаврів приділяється розвитку практичних умінь і навичок, а найважливішими якостями вищої освіти в Україні є її фундаментальність, науковість і надмірність предметного змісту щодо певного виду профресійної діяльності випускника [10].

Нові стандарти підготовки вчителів математики відповідають ідеям компетентнісного підходу, який визначає цільову орієнтацію навчального процесу на фрормування педагогічних, професійних і предметних компетентностей. На жаль, сьогодні у стандартах та інших нормативних документах чітко не розділені сорери діяльності бакалавра і магістра освіти.

Аналіз освітніх стандартів вищої профресійної освіти за напрямом підготовки 01 «Педагогічна освіта» для спеціальності 014 Середня освіта (Математика) ступінь «бакалавр» [4] показує, що студенти після закінчення бакалаврату повинні мати такі фахові компетентності:

- фундаментальні знання 3 математичних дисциплін і перспективних напрямів їх застосування;

- сучасні уявлення про застосування математичних методів у шкільній практиці;

- здатність використовувати основні закони математичних дисциплін у професійній діяльності, застосовувати методи математичного аналізу і моделювання, теоретичного й експериментального дослідження;

- здатність застосовувати інноваційні технології у вивченні математики у середній школі;
- здатність усвідомлювати основні проблеми предметної сорери, визначати методи та засоби їх вирішення;

- здатність профресійно використовувати сучасні методи та засоби навчання математики.

Слід зазначити, що основна освітня бакалаврська програма підготовки вчителів математики встановлює мінімальні вимоги до знань, умінь і навичок студентів за вказаними вище компетентностями. Різке скорочення числа годин у бакалавраті на математичні дисципліни, як показує практика, призводить до того, що у студентів не зовсім фрормуються предметні знання, вміння і навички та проголошені сучасними стандартами компетентності, якими повинен володіти сучасний вчитель математики.

Якщо залишатися в рамках підготовки бакалаврів за чинними навчальними планами, то потрібно терміново шукати еоективні шляхи і засоби підвищення якості математичної підготовки студентів. Підготовка майбутніх вчителів математики за новими освітніми стандартами вимагає активізації самостійної роботи студентів, яка дозволяє поряд із предметними знаннями опановувати ті види діяльності, які характерні для майбутньої професійної діяльності. Збільшення частки самостійної роботи студентів тягне за собою іншу методику організації лекційних і практичних занять [10].

Тому одним із напрямів вдосконалення системи підготовки вчительських кадрів, в т. ч. і вчителів математики, є створення адекватної нової моделі навчання. Головними відмітними ознаками нової моделі від колишньої є: фрокусування уваги на необхідності отримання освіти протягом усього життя (в новій моделі освіта принципово розуміється як незавершене); ідея гнучких і незавершених освітніх траєкторій стає ядром, навколо якого вибудовуються інновації, що охоплюють всі рівні та складові частини освітньої системи; перетворення вищої освіти широкого профрілю (бакалаврат) у ядро освітньої системи; надання студентам широкого аспекту систематично оновлюваних магістерських програм, програм профресійної та загальнокультурної підготовки та перепідготовки; відмова від жорстких кордонів системи освіти, оскільки оновлення компетентностей і отримання академічних кредитів може відбуватися і на фрормуванні знань і технологій; у системі безперервної освіти ключовим фактором стає самостійний доступ студентів до навчальних ресурсів і технологій самоосвіти; мотивація, інтерес, схильності студентів розглядаються в новій моделі як ключовий і найбільш дорогий ресурс результативності освіти; орієнтація нової моделі на справжню відкритість системи освіти, на фрормування її мережевої взаємодії з іншими інститутами; менеджмент якості освіти на основі бально-рейтингової системи для оцінки рівня оволодіння студентами навчальними дисциплінами. 
Цей напрям вдосконалення підготовки висококваліфікованих кадрів, у т. ч. і вчителів математики, пов'язують зі створенням відкритої системи безперервної освіти, яка дозволить регіональним вишам стати конкурентоспроможними. Відкрита система безперервної освіти повинна забезпечити як підготовку висококваліфікованих кадрів, так і підвищення їх професійної майстерності.

Таким чином, на стан професійної підготовки майбутніх вчителів впливає сукупність внутрішніх фракторів (освітні програми і стандарти, методична оснащеність, організація навчального процесу тощо) та зовнішніх (державні стандарти, нормативно-правові документи, запити освітніх установ). Перспективи подальших розвідок вбачаємо у визначенні критеріїв, показників і характеристик означених понять у напрямку вдосконалення підготовки вчителів математики.

\section{БІБЛІОГРАФІЧНИЙ СПИСОК:}

1. Біляковська О. Професійна підготовка майбутніх вчителів природничо-математичних дисциплін: якісний вимір. Збірник наукових праць «Педагогічні науки». Херсон, 2017. Вип. LXXX. T. II. C. 125-129. URL: http://ps.stateuniversity.ks.ua/ arkhiv-vidannya?id=84.

2. Кремень В.Г. Інноваційність і освіта. Моделі розвитку сучасної української школи : Матеріали Всеукраїнської наук.-практ. конференції. Київ : СПБ Богданова А.М., 2007. С. 9-14.

3. Лебедєва І.Л., Норік Л.О. ЗНО з математики: про що свідчать результати (порівняльний аналіз методичних підходів та результатів тестування). Фізико- математична освіта. 2019. Вип. 1. С. 102-107. URL: http://nbuv.gov.ua/UJRN/fmo_2019_1_18.

4. Стандарт вищої профессійної освіти за напрямом підготовки 01 «Педагогічна освіта» для спеціальності 014 Середня освіта (Математика) ступінь «бакалавр»). Переяслав-Хмельницький, 2018. 85 c.

5. Офріційний звіт проведення в 2019 році зовнішнього незалежного оцінювання результатів навчання, здобутих на основі повної загальної середньої освіти. T. 2. URL: https://dneprtest.dp.ua/docs/2017/pdf/zvit_ zno 2018 tom 2.pdf.

6. Пассов Е.И. Мастерство и личность учителя: на примере преподавания иностранного языка. Москва : Флинта: Наука, 2001. 240 с.

7. Рябуха А.Ю. Підготовка майбутніх учителів природничо-математичних дисциплін до застосування мультимедійних технологій : дис. ... канд. пед. наук : 13.00.04. Полтава, 2016. 282 с.

8. Теплицька А.О. Професійна підготовка майбутнього вчителя математики як об'єкт теоретичного аналізу. Наукові праці [Чорноморського державного університету імені Петра Могили комплексу «Києво-Могилянська академія»]. Серія : Педагогіка. 2016. Т. 269. Вип. 257. С. 125-130.

9. Триус Ю.В. Інноваційні інфрормаційні технології у навчанні математичних дисциплін. Інноваційні комп'ютерні технології у вищій школі : матеріали 3 Науково-практичної конференції, 8-12 жовтня 2011 р., Львів / Національний університет «Львівська політехніка». Львів : Видавництво Львівської політехніки, 2011. С. 61-68.

10. Шевчук Л.Д. Профресійна підготовка майбутнього вчителя математики у процесі навчання у ВН3. Рідна школа. 2016. Вип. № 11-12. С. 56-63. 